\title{
Facial asymmetry: silent sinus syndrome
}

\author{
Naseem Eisa, ${ }^{1}$ Abdul Hamid Alraiyes, ${ }^{2}$ M Chadi Alraies ${ }^{1}$
}

1 Department of Hospital Medicine, Cleveland Clinic, Cleveland, Ohio, USA

${ }^{2}$ Department of Pulmonary Diseases, Critical Care, \& Environmental Medicine, Tulane University Health Sciences Center, New Orleans, Louisiana, USA

\section{Correspondence to} Dr M Chadi Alraies, alraies@hotmail.com
To cite: Eisa $\mathrm{N}$, Alraiyes AH, Alraies MC. BMJ Case Rep Published online: [please include Day Month Yearl doi:10.1136/ bcr-2013-010377

\section{DESCRIPTION}

A 23-year-old woman presented to the primary care clinic with a 10-month history of progressive left facial asymmetry, sinking of left eye and deepening of the superior palpebral sulcus. She denied headache, periocular pain, double vision, scalp or face tenderness. Her medical history was negative for sinus tumours, trauma, surgery or allergic rhinosinusitis. Physical examination showed leftsided enophthalmos with hypoglobus, sunken sulcus appearance to the left upper lid and leftsided deviation of the nasal septum with no obvious infection, the rest of ophthalmic examination was intact. CT of the orbits and sinuses (figure 1) revealed left enophthalmos, downward retraction of the orbital floor, total mucosal opacification and reduced volume of the left maxillary sinus. Diagnosis of silent sinus syndrome was made.

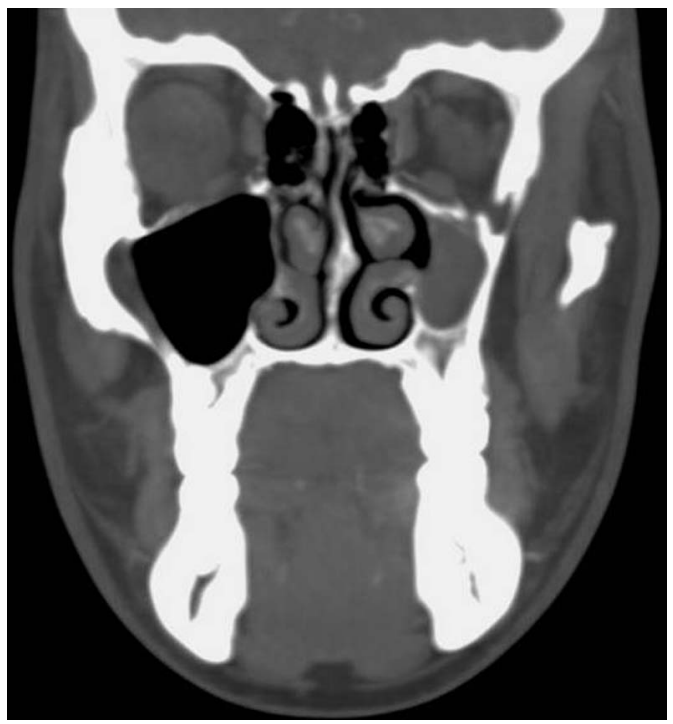

Figure $1 \mathrm{CT}$ of the orbits and sinuses reveals left enophthalmos, downward retraction of the orbital floor, total mucosal opacification and reduced volume of the left maxillary sinus.
The patient was managed with endoscopic sinus surgery to drain and aerate the left maxillary sinus, to repair the left orbital floor and to correct the hypoglobus and enophalmos. Microscopic examination of the antral mucosal specimen showed mild chronic inflammatory changes with no bacterial growth. Her postoperative recovery was uneventful, on 3-months follow-up; she reported complete resolution of symptoms with no recurrence.

\section{Learning points}

- Silent sinus syndrome (SSS) is a rare disorder that is defined as spontaneous and gradual retraction of the maxillary sinus. ${ }^{1-3}$

- Symptoms are usually unilateral and include orbital asymmetry, deepening of superior sulcus, sinking or pulling sensation of the eye, lid lag or nasal shift toward the affected sinus.

- Early recognition and appropriate management of SSS would significantly protect orbital and maxillary sinuses from destruction and collapse and halt further complications.

Competing interests None.

Patient consent Obtained.

Provenance and peer review Not commissioned; externally peer reviewed.

\section{REFERENCES}

1 Sesenna E, Oretti G, Anghinoni ML, et al. Simultaneous management of the enophthalmos and sinus pathology in silent sinus syndrome: a report of three cases. I Craniomaxillofac Surg 2010;38:469-72.

2 Sivasubramaniam R, Sacks R, Thornton M. Silent sinus syndrome: dynamic changes in the position of the orbital floor after restoration of normal sinus pressure. J Laryngol Otol 2011;125:1239-43.

3 Numa WA, Desai U, Gold DR, et al. Silent sinus syndrome: a case presentation and comprehensive review of all 84 reported cases. Ann Otol Rhinol Laryngol 2005;114:688-94.

Copyright 2013 BMJ Publishing Group. All rights reserved. For permission to reuse any of this content visit

http://group.bmj.com/group/rights-licensing/permissions.

BMJ Case Report Fellows may re-use this article for personal use and teaching without any further permission.

Become a Fellow of BMJ Case Reports today and you can:

- Submit as many cases as you like

- Enjoy fast sympathetic peer review and rapid publication of accepted articles

- Access all the published articles

- Re-use any of the published material for personal use and teaching without further permission

For information on Institutional Fellowships contact consortiasales@bmjgroup.com

Visit casereports.bmj.com for more articles like this and to become a Fellow 